ANNA CWENER $^{1} \&$ MARCIN NOWAK ${ }^{2}$

${ }^{1}$ Department of Geobotany, Institute of Biology, Maria Curie-Skłodowska University, Akademicka 19, 20-033 Lublin, Poland, e-mail: acwener@wp.pl

${ }^{2}$ Wąska 5/8, 22-400 Zamość, Poland

\title{
ACTUAL STATE AND CHANGES OF FLORA AND VEGETATION IN THE BROCZÓWKA STEPPE RESERVE
}

\begin{abstract}
This paper presents floristic characterization of xerothermic plant associations and analysis of changes of flora within Broczówka steppe reserve. The floristic research was carried out in 2004-2009. Numerous species that were noted here almost 30 years ago were not found in the present study, the size of other populations decreased. Nevertheless, many plant species occurring in the reserve are rare, endangered or protected. Six major plant associations, impoverished form of two ones and one plant community are distinguished in the whole area of the reserve. Occurrence of two plant associations was not confirmed.
\end{abstract}

Key words: steppe reserve, rare and endangered species, succession

\section{INTRODUCTION}

Almost all sites of xerothermic vegetation in middle-east Poland were investigated in respect of flora and plant associations and communities. The researches were conducted in 1960s (e.g. FIJAŁKOWSKI 1959, 1964, 1972; FiJAŁKOWSKI, IZDEBSKI 1957; FiJAŁKOWSKI, ADAMCZYK 1980; FiJAŁKOWSKI et al. 1987). Conducted comparative researches show, that both flora and plant communities have been changed to a great extent. Preliminary information on this theme was published by FiJAŁKOWSKI et al. (1987) and KUCHARCZYK and WóJCIAK (1995). This paper presents floral and ecological characterization of currently occurring xerothermic plant associations and analysis of changes of flora within 
Broczówka steppe reserve. Particular attention was paid to rare and endangered vascular plant species.

\section{MATERIALS AND METHODS}

Broczówka nature reserve located about 1.5 km north-east of Skierbieszów is a part of Skierbieszów Landscape Park. It is situated in the south-east part of the Lublin Upland, in the mesoregion of Działy Grabowieckie (CHAŁUBIŃSKA, WILGAT 1954; KONDRACKI 1994, 2000).

Broczówka nature reserve was established in 1989 for conservation of xerothermic plant associations with rare and protected plant species. It covers a part of a $40 \mathrm{~m}$ high hill's slope of about $50^{\circ}$ inclination and south-western exposition. In the north and north-east the reserve borders on arable fields. A small forest complex adjoins the south-eastern part of the reserve. At the foot of the reserve in its southwestern part, there's a strip of hay-growing meadow (DUDA, PRÓCHNICKI 1998). The area of Broczówka reserve (about $6 \mathrm{ha}$ ) is geomorphologically diversified. There are many erosional forms both in the loess and Cretaceous rock formations. Chalky marls that are exposed in the lower and middle section of the slope are covered by a few meters thick loess layer in its upper part. Brown soils are developed on loess and rendzinas on chalky marls, respectively (FIJAŁKOWSKI, ADAMCZYK 1980; DUDA, PRÓCHNICKI 1998).

The floristic research in Broczówka reserve was carried out in 2004-2009. Every plant species occurring in the reserve area was recorded, but special attention was paid to rare, endangered and protected species. A list of rare species was prepared according to Red list of plants and fungi in Poland (MIREK et al. 2006), red list of vascular plants in the Lublin Region (KUCHARCZYK 2004), the order of the Minister of the Environment from July $9^{\text {th }} 2004$ and Distribution Atlas of Vascular Plants in Poland (ZAJĄC, ZAJĄC 2001). The botanical terminology was taken from MiREK et al. (2002). The categories of threat of species in Poland were given according to MIREK et al. (2006) and in the Lublin Region according to KUCHARCZYK (2004). A scale analogous to the one presented by FIJAŁKOWSKI and ADAMCZYK (1980) was used in determining the frequency of species. 
Plant associations were examined according to the BRAUN-BLANQUET (1964) method. The phytosociological terminology and taxonomy of plant associations was taken from MATUSZKIEWICZ (2001). The affilation of particular species to plant associations was also determined according to MATUSZKIEWICZ (2001). To describe vegetations changes, the Shannon - Wiener index of diversity $(\mathrm{H})$ and index of evenness ( $\left.\mathrm{J}=\mathrm{H}_{\mathrm{observed}} / \mathrm{H}_{\max }\right)$ were counted (SHANNON, WEAVER 1949).

\section{RESULTS}

\section{Flora and its changes}

257 species of vascular plants occur in the area of the reserve. Rare and endangered, in that listed by FIJAŁKOWSKI and ADAMCZYK (1980), are presented in Table 1.

In the area of the reserve, the most interesting are xerothermic plants e.g. Asperula tinctoria, Carex praecox, Cerasus fruticosa, Elymus hispidus, Orobanche alsatica - species included in the Red list of plants and fungi in Poland. Moreover, 19 species are protected (13 strictly, 6 partially), among them: Aster amellus, Campanula sibirca, Cirsium pannonicum, Clematis recta, Primula veris, Daphne mezereum, Neottia nidus-avis, Frangula alnus, Viburnum opulus. Other 12 species are endangered on Lublin region e.g: Asperula cynanchica, Inula ensifolia, I. hirta, Carex humilis, Crepis praemorsa, Tanacetum corymbosum, Thesium linophyllon. In the reserve area abundant are xerotherimc species: Peucedanum cervaria, Teucrium chamaedrys, Scabiosa ochroleuca, Stachys recta, Anthericum ramosum, Salvia pratensis and S. verticillata. But flora has changed for last 30 years (Tab 1.). The size of numerous xerothermic plants populations decreased, for example: Cerasus fruticosa, Anemone sylvestris, Anthemis tinctoria, Elymus hispidus, Clematis recta and Inula hirta. According to FIJAŁKOWSKI and ADAMCZYK (1980) the population of Inula hirta was almost as numerous as Inula ensifolia, and at present only a few flowering plants were found. Similarly, Cerasus fruticosa occupied a patch of $100 \mathrm{~m}^{2}$ area, at present only few plants grow. The number of termophilous shrubs and forest species changed in less degree. Numerous species that were noted here 30 
years ago were not found in the present study (Tab 1, Fig. 1.). Many of them (33 from 71) are rare xerothermic species belonging to Festuco-Bromea class,

Table 1. List of rare and endangered species noted in the Broczówka reserve. Explanations: * - strict protected species, ** - partial protected species; syntaxonomical group: Av - Artemisietea vulgaris, F-B - Festuco-Brometea, CirsBrach - Cirsio-Brachypodion pinnati, Fes val - Festucetalia valesiaceae, Fest-Stip - Festuco-Stipion, Q-F - Querco-Fagetea, Que pub - Quercetalia pubescentipetraeae, Sm - Stellarietea mediae, Caucalid - Caucaliodion lappulae, K-C Koelerio glaucae-Corynephoretea, M-A - Molinio-Arrhenatheretea, R-P Rhamno-Prunetea, T-G - Trifolio-Geranietea, Th - Thlaspietea rotundifolii, V-P Vaccinio-Piceetea; LR - the category of threat in the Lublin Region (KUCHARCZYK 2004): CR - critically endangered species, EN - endangered species, VU vulnerable species, LR - species of lower risk; PL - the category of threat in Poland (MIREK et al. 2006): E - declining - critically endangered species, V - vulnerable species, $\mathrm{R}$ - rare - potentially endangered species; frequency on the area of reserve: 1 - single or a few specimens, 2 - 10-50 specimens; 3 - 50-100 specimens; 4 - species occurring in large number within $50-100 \mathrm{~m}^{2} ; 5$ - species forming patches $100-1000 \mathrm{~m}^{2} ; 6$ - species forming patches over $1000 \mathrm{~m}^{2} ;+$ species listed in phytosociological tables.

\begin{tabular}{|c|c|c|c|c|c|c|}
\hline & \multirow{2}{*}{ Name } & \multirow{2}{*}{$\begin{array}{c}\text { Syntaxonomical } \\
\text { group }\end{array}$} & \multirow{2}{*}{ LR } & \multirow{2}{*}{ PL } & \multicolumn{2}{|c|}{ Frequency } \\
\hline & & & & & 1980 & 2007 \\
\hline 1 & Adonis vernalis* & F-B & VU & $\mathrm{V}$ & 1 & - \\
\hline 2 & Allium montanum & F-B & EN & & 2 & - \\
\hline 3 & Anemone sylvestris* & T-G & & & 5 & 2 \\
\hline 4 & Aquilegia vulgaris* & Q-F (Que pub) & & & 2 & - \\
\hline 5 & Asperula tinctoria & F-B & VU & $\mathrm{V}$ & 2 & 3 \\
\hline 6 & Asarum europaeum** & Q-F & & & - & 5 \\
\hline 7 & Aster amellus* & F-B (Cirs-Brach) & LR & & + & 2 \\
\hline 8 & A. danicus & F-B & EN & & 1 & - \\
\hline 9 & A. onobrychis & F-B & VU & & 2 & - \\
\hline 10 & Botrychium lunaria* & $\mathrm{N}-\mathrm{C}$ & & $\mathrm{V}$ & 1 & - \\
\hline 11 & Campanula bononiensis* & F-B (Cirs-Brach) & & & 3 & - \\
\hline 12 & C. sibirica* & F-B & & & 4 & 3 \\
\hline 13 & Carex humilis & F-B & VU & & 6 & 5 \\
\hline 14 & C. michelii & F-B (Cirs-Brach) & LR & & 3 & 2 \\
\hline 15 & C. supina* & F-B (Fest-Stip) & EN & $\mathrm{R}$ & 1 & - \\
\hline 16 & C. transsilvanica & F-B & VU & & 3 & - \\
\hline 17 & C. umbrosa & Q-F & LR & $\mathrm{R}$ & 1 & - \\
\hline 18 & Centaurium erythraea* & M-A & & & 2 & 1 \\
\hline 19 & Cerasus fruticosa* & R-P & $\mathrm{CR}$ & $\mathrm{V}$ & 4 & 1 \\
\hline 20 & Cimcifuga europaea* & Q-F (Que pub) & VU & & 1 & - \\
\hline 21 & Cirsium pannonicum* & F-B (Cirs-Brach) & EN & & 5 & 4 \\
\hline 22 & Clematis recta* & T-G & VU & & 3 & 2 \\
\hline 23 & Crepis praemorsa & F-B & VU & & 2 & 1 \\
\hline 24 & Cyperipedium calcelous* & Q-F (Que pub) & VU & $\mathrm{V}$ & 1 & . \\
\hline
\end{tabular}


Table 1. (Continued)

\begin{tabular}{|c|c|c|c|c|c|c|}
\hline 25 & Daphne mezereum* & $\mathrm{Q}-\mathrm{F}$ & & & 2 & 3 \\
\hline 26 & Dianthus carthusianorum & F-B & & & 5 & - \\
\hline 27 & Digitalis grandiflora* & Q-F (Que pub) & & & 2 & - \\
\hline 28 & Echium russicum* & F-B & $\mathrm{CR}$ & $\mathrm{E}$ & 1 & - \\
\hline 29 & Elymus hispidus & F-B (Cirs-Brach) & LR & $\mathrm{R}$ & 5 & 2 \\
\hline 30 & Festuca rupicola & F-B & $\mathrm{EN}$ & & 4 & 1 \\
\hline 31 & Festuca valesiaca & F-B (Fest-Stip) & $\mathrm{EN}$ & $\mathrm{V}$ & 3 & - \\
\hline 32 & Frangula alnus $* *$ & V-P & & & - & 4 \\
\hline 33 & Galium odoratum** & Q-F & & & - & 3 \\
\hline 34 & Gentiana cruciata* & F-B & VU & & 1 & - \\
\hline 35 & Hedera helix** & Q-F & & & 5 & - \\
\hline & Helianthemum & & & & & \\
\hline 36 & $\begin{array}{l}\text { nummularium subsp. } \\
\text { obscurum }\end{array}$ & F-B & & & 5 & - \\
\hline 37 & Hepatica nobilis* & Q-F & & & - & 6 \\
\hline 38 & Hieracium echioides & $\mathrm{K}-\mathrm{C}$ & VU & $\mathrm{V}$ & 2 & - \\
\hline 39 & Hierochloe australis** & V-P & VU & $\mathrm{V}$ & + & - \\
\hline 40 & Hypochoeris maculata & F-B & & & 1 & - \\
\hline 41 & Inula ensifolia & F-B (Cirs-Brach) & VU & & 6 & 6 \\
\hline 42 & I. hirta & $\mathrm{T}-\mathrm{G}$ & VU & & 5 & 1 \\
\hline 43 & Iris aphylla* & F-B (Cirs-Brach) & VU & $\mathrm{V}$ & 1 & - \\
\hline 44 & Koeleria macrantha & F-B & VU & & 5 & 1 \\
\hline 45 & Lilium martagon* & Q-F & & & 2 & - \\
\hline 46 & Linosyris vulgaris* & F-B & $\mathrm{EN}$ & $\mathrm{R}$ & 2 & - \\
\hline 47 & Linum flavum* & F-B (Cirs-Brach) & $\mathrm{EN}$ & $\mathrm{R}$ & 1 & - \\
\hline 48 & Melittis melissophyllum* & Q-F (Que pub) & & & 4 & 2 \\
\hline 49 & Neottia nidus-avis* & Q-F & & & - & 2 \\
\hline 50 & Ononis arvensis** & F-B & & & - & 1 \\
\hline 51 & Orchis militaris* & F-B (Cirs-Brach) & $\mathrm{EN}$ & $\mathrm{V}$ & 1 & - \\
\hline 52 & Orobanche alsatica* & F-B & & $\mathrm{E}$ & - & 2 \\
\hline 53 & Potentilla recta & F-B & & & 2 & - \\
\hline 54 & Primula veris** & Q-F (Que pub) & & & 4 & 3 \\
\hline 55 & Rosa gallica* & Q-F (Que pub) & $\mathrm{CR}$ & $\mathrm{V}$ & 1 & - \\
\hline 56 & R. majalis & R-P & $\mathrm{EN}$ & & 1 & - \\
\hline 57 & R. tomentosa & R-P & VU & & 2 & 1 \\
\hline 58 & Sanguisorba minor & F-B & & & 5 & - \\
\hline 59 & Scorzonera purpurea* & F-B & $\mathrm{EN}$ & $\mathrm{V}$ & 1 & - \\
\hline 60 & Tanacetum corymbosum & Q-F (Que pub) & VU & & 4 & 3 \\
\hline 61 & Thalictrum minus & $\mathrm{T}-\mathrm{G}$ & VU & & 5 & 2 \\
\hline 62 & Th. simplex & F-B & VU & & 1 & 1 \\
\hline 63 & Thesium linophyllon & F-B & VU & & 4 & 4 \\
\hline 64 & Thlapsi perfoliatum & F-B & $\mathrm{EN}$ & & 1 & - \\
\hline 65 & Trifolium rubens & $\mathrm{T}-\mathrm{G}$ & VU & & 1 & - \\
\hline 66 & Veronica austriaca & F-B & VU & & 4 & - \\
\hline 67 & $V \cdot$ prostrata & F-B & VU & & 1 & - \\
\hline 68 & Viburnum opulus** & R-P & & & - & 4 \\
\hline 69 & Viola collina & Q-F (Que pub) & VU & & 3 & - \\
\hline 70 & $V$. rupestris & F-B & & & 4 & - \\
\hline
\end{tabular}


e.g. Adonis vernalis, Echium russicum, Linosyris vulgaris, Linum flavum, Rosa gallica, Scorzonera purpurea, Orchis militaris, Gentiana cruciata, Iris aphylla. Iris aphylla extincted and it was reintroduced in 1995 (DĄBROWSKA et al. 2000). During the present study not even a single plant was found. Also some of rare forest species, e.g. Aquilegia vulgaris, Cypripedium calceolus, Cimicifuga europaea were not found at present. Also some termophilous plants that often occur on abandoned land, e.g. Fumaria vallianti, Lathyrus tuberosus, Melampyrum arvense, Stachys annua, Euphorbia falcata, E. platyphyllos, were not found.

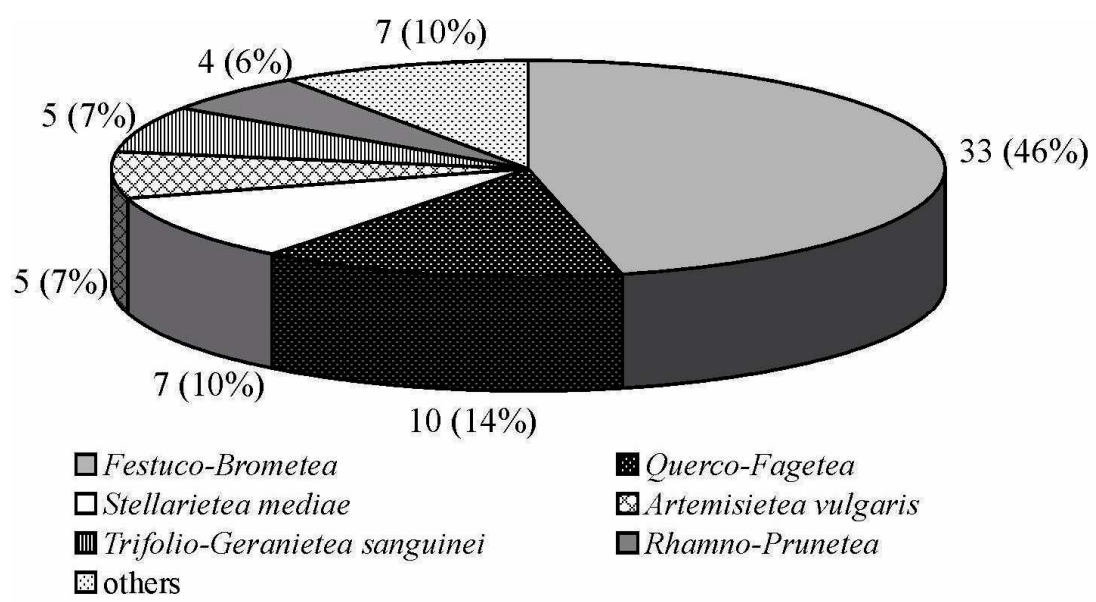

Fig. 1. Number of extinct species from particular syntaxonomical groups in the Broczówka reserve.

\section{Vegetation cover and its changes}

Six major plant associations are distinguished in the whole area of the reserve. Also two impoverished associations and one community were noted. Their syntaxonomic position can be presented as follows:

Class: Festuco-Brometea Br.B1. er R.Tx. 1943

Order: Festucetalia valesiacae Br.Bl. er R.Tx. 1943

Alliance: Cirsio-Brachypodion pinnati Hadač et Klika 1944 em. Krausch 1961

Association: Inuletum ensifoliae Kozł. 1925 
Impoverished form of Thalictro-Salvietum pratensis Medw.-Korn. 1959

Community with Brachypodium pinnatum

Class: Trifolio-Geranietea sanguinei Th. Müller 1962

Order: Origanetalia Th. Müller 1962

Alliance: Geranion sanguinei R. Tx. 1961

Association: Geranio-Peucedanetum cervariae (Kuhn 1937) Th. Müller 1961

Class: Rhamno-Prunetea Rivas Goday et Garb. 1962

Order: Prunetalia spinosae R. Tx. 1952

Alliance: Pruno-Rubion fruticosi R. Tx. 1952 corr. Doing 1962

Association: Rubo fruticosi-Prunetum spinosae Web. 1974 n.inv. Wittig 1976

Alliance: Berberidion Br.-Bl. (1947)1950

Association: Rhamno-Cornetum sanguinei (Kais. 1930) Pass. (1957)1962

Class: Querco-Fagetea Br.-Bl. et Vlieg 1937

Order: Quercetalia pubescenti-petrae Klika 1933 corr. Moravec in Beg. et Theurill 1984

Alliance: Potentillo albae-Quercion petraeae Zól et Jakucs n.nov. Jakucs 1967

Impoverished form of Potentillo albae-Quercetum Libb. 1933

Order: Fagetalia sylvatica Pawł., in Pawł., Sokoł. et. Wall 1928

Alliance: Carpinion betuli Issl. 1931 em. Oberd. 1953

Association: Tilio cordate-Carpinetum betuli Tracz. 1962

Association: Ficario-Ulmetum minoris Knapp 1942 em. J. Mat. 1976

Upper section of the slope and the top of the hill with a thick layer of loess cover is occupied by Tilio-Carpinetum forest. Carpinus betulus with Fagus sylvatica, Populus tremula and Prunus avium occur within the tree stand. In the southern part of the reserve Pinus sylvestris (planted here in the 1970's) has large 
participation in the tree stand. In the shrub layer Corylus avellana predominates with Euonymus verrucosus, Cornus sanguinea and trees saplings. Undergrowth is mainly represented by: Asarum europaeum, Hepatica nobilis, Pulmonaria obscura and in spring Anemone nemorosa. Within lower, more sunlit parts of the slope Quercus robur, Pinus sylvestris, Pyrus communis and Malus sp. occur in the tree stand. In the shrub layer, Euonymus verrucosus, Cornus sanguinea and Crataegus monogyna are noted. Daphne mezereum grows (sometimes in abundance) in lower layers. In the undergrowth Melampyrum nemorosum, Melica nutans occur, and in more sunny places Brachypodium pinnatum and B. sylvaticum are found. Within one of loess prominences among shrubs grow singly Potentilla alba, Inula hirta and Rubus saxatilis. These species are connected with Potentillo albae-Quercetum petrae forests. However, in deep ravines, where an intensive surface flow occurs, species growing on moisture and rich soils are noted. In such places, fragments of humid dry-ground forest referring to Ficario-Ulmetum develop. In the tree stand of this area Fraxinus excelsior and Alnus incana occur and in undergrowth Rubus caesius, Ficaria verna, Aegopodium podagraria and Urtica dioica appear.

At the hill's foot the stripe of shrubs from the Rhamno-Prunetea class occurs. In the vicinity of hay-growing meadow, the Rubo fruticosi-Prunetum spinosae association develops. It is mainly represented by Prunus spinosa, and in poor undergrowth by Stellaria holostea and Poa nemoralis. Within shrubs communities over the stripe of Prunus spinosa occur: Rhamnus catharticus, Cornus sanguinea, Euonymus europaeus and E. verrucosus, Viburnum opulus, Frangula alnus and Crataegus monogyna. The association Rhamno-Cornetum sanguinei is also present here. In one of the clearings Corylus avellana with Carpinus betulus, Quercus robur and Rosa canina form a low-density brushwood. In the undergrowth, Brachypodium pinnatum and Peucedanum cervaria are predominant and they occur with numerous species from the Festuco-Brometea class. In the previous studies such plant community was described as the Peucedano cervaria-Coryletum association, at present it was classified as Geranio-Peucedanetum cervariae.

The xerothermic grasslands are the most valuable in the reserve. They occupy a shallow-soil area in the central and lower parts of the slope. In places with 
the shallowest soil, mostly within central parts Inuletum ensifoliae association develops. In this association Inula ensifola is predominant with a large participation of: Carex humilis, Cirsium pannonicum, Thesium linophyllon, Prunella grandiflora and Asperula tinctoria. Less frequent is Aster amellus, which is characteristic for this association. Often in the Inuletum ensifoliae grasslands different species of shrubs appear: e.g. Juniperus communis, Cornus sanguinea, Rhamnus catharticus and Quercus robur. Within a small area, on a relatively deeper soil, impoverished form of the Thalictro-Salvietum pratensis association occurs. In this association characteristic for this association Elymus hispidus s.l., Carex praecox, Potentilla arenaria and Thalictrum minus are noted. Those grasslands are overgrown by shrubs, especially Prunus spinosa.

On the edge of clearings occupied by Inuletun ensifoliae, transitional, rich in species, plant communities form. In these communities, Brachypodium pinnatum or Inula ensifolia with Peucedanum cervaria predominates interchangeably. Aside from species of the Festuco-Brometea class, plants characteristic for TrifolioGeranietea sanguinei grow here, e.g. Clematis recta, Anemone sylvestris, Coronilla varia, Origanum vulgare, but also species included to the ordo Quercetalia pubescentis, e.g. Melittis melissophyllum, Tanacetum corymbosum, Vincetoxicum hirundinaria or Campanula persicifolia. Abundant are: Galium verum, Geranium sanguineum, Lembotropis nigricans, Chamaecytisus ruthenicus. Fragments of such communities, the with domination of Peucedanum cervaria and other species from Quercetalia pubescentis abundance may be classified as the Geranio-Peucedanetum cervariae association. Fragments with the domination of Brachypodium pinnatum and other mesophilic species, e.g. Salvia pratensis, Achillea pannonica abundance, may be described as a community with Brachypodium pinnatum. This community develops in a place that was cultivated in the past so accompanying species have great share in it.

The vegetation units, especially area and structure, of grasslands have changed since the researches conducted by FIJAŁKOWSKI and ADAMCZYK (1980). The xerothermic grasslands associations have became poorer in species and more homogenous. Both the number of species forming individual communities and the 
index of diversity have decreased. The diminishing index of evenness indicates that some of species dominate in communities while others have fewer shares in plant cover (Tab. 2). Only very impoverished fragments of Thalictro-Salvietum pratensis left. Similarly, a few specimens of Potentilla alba may indicate past existence of Potentillo albae-Quercetum. Also occurrence of Prunetum fruticoseae was not confirmed at present study. In all xerothermic grasslands associations and communities number of species from Festuco-Brometea decreased, on the contrary, number of taxons from other group increased (Fig. 2). Inuletum ensifoliae reshapes in communities from the Trifolio-Geranietea class, however community with Brachypodium pinnatum overgrows by shrubs and trees from the Rhamno-Prunetea and Querco-Fagetea classes.

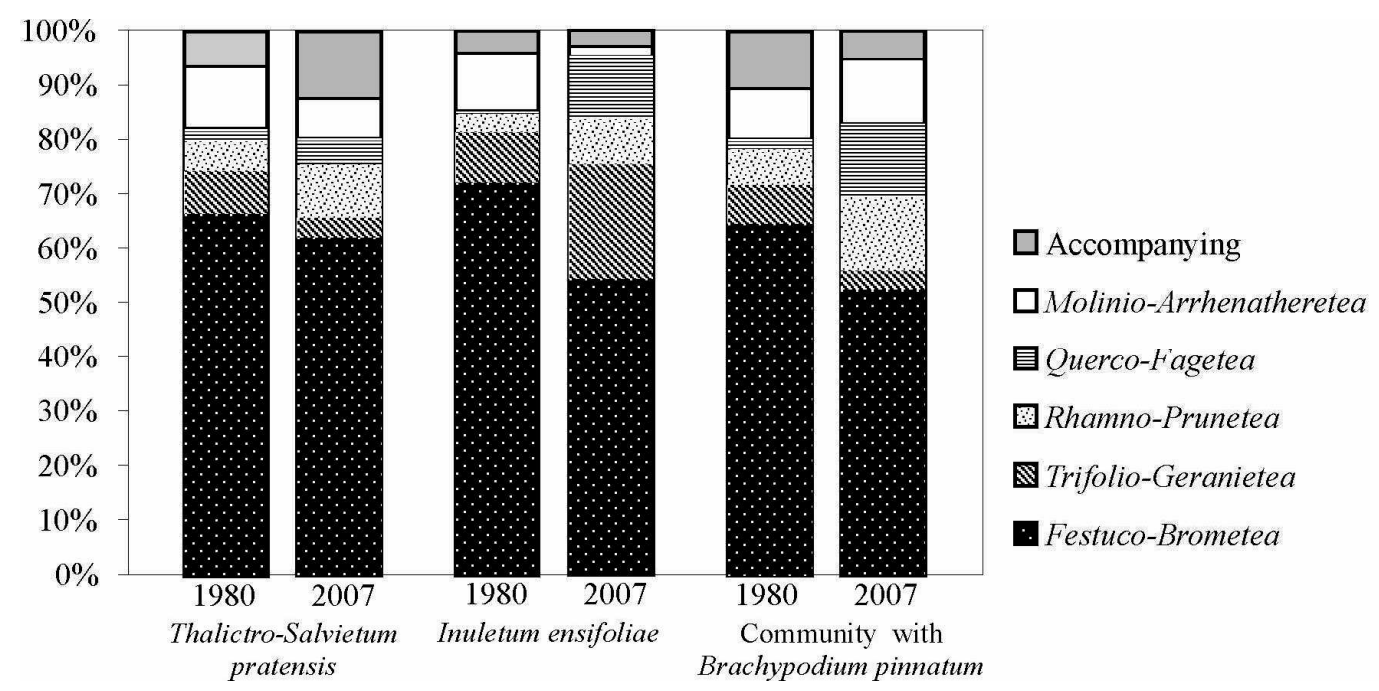

Fig. 2. Changes in share of syntaxonomical groups in xerothermic grasslands communities.

\section{DISCUSSION AND CONCLUSIONS}

There are several data on xerothermic flora of the Działy Grabowieckie and on the Lublin Upland (e.g. FIJAŁKOWSKI 1959, 1964, 1972; FIJAŁKOWSKI, IZDEBSKI 1957; FiJAŁKOWSKi, AdAMCZYK 1980; FiJAŁKOWSKi et al. 1987). So, it may be concluded that xerothermic species are endangered and their populations decrease. In the area of Broczówka reserve, numerous species that were noted here 27 years 
ago were not found in the present study, e.g. Echium russicum, Adonis vernalis, Rosa gallica and Iris aphylla. The size of others e.g. Cerasus fruticosa and Inula hirta populations decreased. Also composition and structure of plant communities have changed. Grasslands associations become poorer, and area of shrubs communities increases. Three of distinguished here by FIJAŁKOWSKI and ADAMCZYK (1980) plant communities were not identified in the present studies: Potentillo albae-Quercetum, Ulmetum campestris suberosae, Prunetum fruticosae and Adonido-Brachypodietum pinnati was recognized as community with Brachypodium pinnatum.

Table 2. Changes of floristic diversity in xerothermic grasslands in the Broczówka reserve.

\begin{tabular}{lcccccc}
\hline & \multicolumn{2}{c}{$\begin{array}{c}\text { Thalictro- } \\
\text { Salvietum } \\
\text { pratensis }\end{array}$} & \multicolumn{2}{c}{$\begin{array}{c}\text { Inuletum } \\
\text { ensifoliae }\end{array}$} & \multicolumn{2}{c}{$\begin{array}{c}\text { com. } \\
\text { Brachypodium } \\
\text { pinnatum }\end{array}$} \\
\cline { 2 - 8 } & 1980 & 2007 & 1980 & 2007 & 1980 & 2007 \\
\hline Average nuber of & & & & & & \\
species in releve & 50.0 & 49.0 & 53.0 & 28.5 & 51.0 & 29.5 \\
Index of diversity (H) & 1.70 & 1.58 & 1.68 & 1.37 & 1.65 & 1.33 \\
Index of evennes (J) & 0.99 & 0.98 & 0.99 & 0.95 & 0.97 & 0.96 \\
\hline
\end{tabular}

The changes that have place in Broczówka reserve are analogous to those observed in other steppe reserves and generally in xerothermic grasslands (e.g. KAPUŚCIŃSKI 1990; MiCHALIK 1990a, 1990b; SENDEK, BABCZYŃSKA-SENDEK 1990; ŚWIERCZYŃSKA 1990; DZWONKO, LOSTER 1992; MiCHALIK, ZARZYCKI 1995; BĄBA 2003). The major therat for xerothermic plants is vegetation sucession. The trees and shrubs appearing in grasslands overshade photophilic species and inhibit their growth. Moreover, trees and shurbs decrease evaporation favoring the growth of mesophilic species. Cutting down the trees and shrubs from the central parts of clearings is done for protection of xerothermic flora in Broczówka reserve. Such treatment is favorable for xerothermic species, but seems to be insufficient. It only temporarily reduces shading and it is necessary to repeat it frequently. To improve the protection, the trees and shrubs should be cut down at least from two bigger clearings (not only from central but also from its peripheral parts). It would improve 
the microclimatic condition, decrease shading and increase evaporation. Another danger for xerothermic flora is destroying the plants by people digging them up and moving to gardens. It doesn't cause a big danger if it is limited to common species, but when the species is rare, it may lead to extintion. It is possible that it happened to Iris aphylla and Adonis vernalis, which disappeared from their natural sites in the reserve.

\section{REFERENCES}

BĄBA, W. 2003. Chhanges in the structure and floristic composition of the limestone-_one. grasslands after cutting trees and shrubs and mowing. Acta Soc. Bot. Pol. 72: 6169.

Braun-Blanquet, J. 1964. Pflanzensoziologie. Springer Verlag, Wien.

ChaŁubińska, A., Wilgat, T. 1954. Podział fizjograficzny województwa lubelskiego. Przewodnik V PT Geogr., Lublin.

DĄBrowska, K., FranszcZaK-Być, M., SAWICKI, R. 2000. Rozmieszczenie i reintrodukcja kosaćca bezlistnego na Lubelszczyźnie. In: J. ŁĘTOWSKI (ed.), Walory przyrodnicze Chełmskiego Parku Krajobrazowego i jego okolic. Wydawnictwo UMCS, Lublin, pp 63-66.

DudA, P., PRÓchnicki, K. 1998. Plan ochrony rezerwatu „Broczówka” na okres od 01.01.1999 roku do 31.12.2018 roku. Zamość.

DZWONKO, Z., LOSTER, S. 1992. Zróżnicowanie roślinności i wtórna sukcesja w murawowo-leśnym rezerwacie Skołczanka koło Krakowa. Ochr. Przyr. 50: 3364.

FIJAŁKOWSKI, D.1959. Drugie stanowisko dziewiećsiłu popłocholistnego (Carlina onopordifolia Bess.) na Wyżynie Lubelskiej. Chrońmy Przyr. Ojcz. 15(2): 16-19.

FIJAŁKOWSKI, D. 1964. Zbiorowiska kserotermiczne okolic Izbicy na Wyżynie Lubelskiej. Ann. UMCS, sec. C. 19: 239-259.

FIJAŁKOWSKI, D. 1972. Stosunki geobotaniczne Lubelszczyzny. Lubelskie Towarzystwo Naukowe, Lublin.

FiAŁKowski, D., AdAmCZYK, B. 1980. Roślinność stepowa w Broczówce k. Skierbieszowa. Annales UMCS sec. C. 35: 65-76. 
FIJAŁKOWSKI, D., IZDEBSKI, K. 1957. Zbiorowiska stepowe na Wyżynie Lubelskiej. Ann. UMCS, sec. B. 12: 167-189.

FIJAŁKOWSKI, D., IZDEBSKI, K., ŚWIERCZYŃSKA, S. 1987. Zmiany antropogeniczne roślinności z klasy Festuco-Brometea na Wyżynie Lubelskiej. Folia Soc. Sci. Lub. 29: 39-45.

KAPUŚCIŃKSI, R. 1990. Zmiany roślinności kserotermicznej w projektowanym rezerwacie "Zapusty" w warunkach ograniczonej ingerencji człowieka. Prądnik. Pr. Muz. Szafera 2: 23-27.

KONDRACKI, J. 1994. Geografia Polski. Mezoregiony fizyczno-geograficzne. Wydawnictwo Naukowe PWN, Warszawa.

KondRACKI, J. 2000. Geografia regionalna Polski. Wydawnictwo Naukowe PWN, Warszawa.

KUCHARCZYK, M. 2004. Lista ginących i zagrożonych gatunków roślin naczyniowych województwa lubelskiego. Wersja 3.2. Lublin. (mscr.).

KUCHARCZYK, M., WóJCIAK, J. 1995. Ginące i zagrożone gatunki roślin naczyniowych Wyżyny Lubelskiej, Roztocza, Wołynia Zachodniego i Polesia Lubelskiego. Ochr. Przyr. 52: 33-46.

MatuszKiewicz, W. 2001. Przewodnik do oznaczania zbiorowisk roślinnych Polski. Wydawnictwo Naukowe PWN, Warszawa.

Medwecka-Kornaś, A., Kornaś, J., PAwŁowski, B., ZarzycKi, K. 1977. Przegląd zbiorowisk roślinnych lądowych i słodkowodnych. In: W. SZAFER, K. ZARZYCKI (eds), Szata roślinna Polski. T. I. PWN, Warszawa, pp. 237-481.

MichaliK, S. 1990a. Przemiany roślinności kserotermicznej w czasie 20-letniej sukcesji wtórnej na powierzchni badawczej "Grodzisko" w Ojcowskim Parku Narodowym. Prądnik. Pr. Muz. Szafera 2: 43-52.

MichALIK, S. 1990b. Sukcesja wtórna półnaturalnej murawy kserotermicznej Origano-Brachypodietum w latach 1960-1984 wskutek zaprzestania wypasu w rezerwacie Kajasówka. Prądnik. Pr. Muz. Szafera 2: 59-65.

MiCHALIK, S., ZARZYCKI, K. 1995. Management of xerothermic grasslands in Poland: botanical approach. Colloques Phytosociologiques. Fitodinamica 24: 881-897. 
Mirek, Z., PięKoŚ-Mirkowa, H., ZajĄC, A., ZAJĄC, M. 2002. Flowering plants and pteridophytes of Poland - a checklist. In: Z. MIREK (ed.), Biodiversity of Poland 1. W. Szafer Insitute of Botany, Polish Academy of Sciences, Kraków.

MireK, Z., ZARZycki, K., WojewOdA, W., SzeląG, Z. 2006. Red list of plants and fungi in Poland. W. Szafer Institute of Botany. Polish Academy of Sciences, Kraków.

SEndeK, A., BABCZYŃSKA-SENDEK, B. 1990. Problemy ochrony roślinności kserotermicznej w rezerwatach Góra Gipsowa i Ligota Dolna na Opolszczyźnie. Prądnik. Pr. Muz. Szafera 2: 17-21.

SHANNON, C.E., WEAVER, W. 1949. The mathematical theory of communication. University of Illinois Press, Urbana.

ŚWIERCZYŃSKA, S. 1990. Problem zachowania zbiorowisk stepowych na podstawie badań prowadzonych na Lubelszczyźnie. Prądnik. Pr. Muz. Szafera 2: 29-34.

ZAJĄC, A., ZAJĄC, M. (eds). 2001. Atlas rozmieszczenia roślin naczyniowych w Polsce. Nakładem Pracowni Chorologii Komputerowej Instytutu Botaniki UJ, Kraków. 